M.I. Baranov

\title{
AN ANTHOLOGY OF THE DISTINGUISHED ACHIEVEMENTS IN SCIENCE AND TECHNIQUE. PART 52: ROCKET-SPACE TECHNOLOGY DESIGNER MIKHAIL YANGEL AND HIS ACCOMPLISHMENTS IN MISSILE DESIGN
}

Purpose. Preparation of short scientifically-historical essay about the distinguished designer of domestic space-rocket technique and one of basic creators of missiles for a Soviet rocket-nuclear "shield» Mikhail Kuzmich Yangel. Methodology. Known scientific methods of collection, analysis and analytical treatment of scientific and technical information, regarding becoming and development in the USSR of space-rocket technique of the military and peaceful applications and resulted in scientific monographs, journals and internet-reports. Results. A short scientifically-historical essay is resulted about the distinguished Soviet designer of space-rocket technique of M.K. Yangel, becoming one of creators of domestic strategic rocket-nuclear «shield». Basic scientific and technical achievements of talented and purposeful scientist-mechanic M.K. Yangel are described, becoming in 1954 Head and Chief Designer of the Special Designer Bureau No. 586 (SDB-586, Dnepropetrovsk city), in area of development and creation of powerful battle ballistic rockets of the strategic applications and missiles for the peaceful mastering of space. It is shown that under scientific guidance of the Chief Designer of SDB-586 (in 1966 it began to be named DB "Southern") M.K. Yangel in the USSR were developed and accepted on the armament of rocket strategic armies the Soviet army: battle strategic rockets of the first generation (rockets with military indexes 8K63, 8K65 and 8K64); battle intercontinents ballistic rockets (ICBR) of the second (rockets with military indexes $8 K 67,8 K 69$ and $8 K 67 \Pi$ ) and the third (rockets with military indexes $15 A 14$ (on terminology of NATO SS-18 «Satan»), 15A15, 15A16 and 15A18) generations. At creation in the USSR of battle ICBR of the fourth generation (rockets with the military indexes of 15A18M, $15 \% 60$ and 15\%61) the ideas of M.K. Yangel were applied. These battle ICBR provided in the period of the "Cold War» for the USSR a party in the world race of strategic rocketnuclear armaments. Powerful domestic missiles are "Space-1", "Space-2»,"Cyclone-2» and "Cyclone-3», created at SDB-586 (DB «Southern») under the guidance of M.K. Yangel on the base of the indicated battle ICBR, executed the tasks laid on them in area of the peaceful mastering of space. Originality. Certain systematization is executed known from mass of scientific and technical materials media, regarding becoming and development in the USSR of rocket industry, having an important militarystrategic and civil value. First for a wide reader the concrete contribution of SDB-586 (DB «Southern»), headed in the period of 1954-1971 by Academician of the Academy of Sciences of the Ukrainian SSR and the Academy of Sciences of the USSR M.K. Yangel is exposed in the concentrated kind, in creation of powerful Soviet battle ICBR, making in the period of 1959-1991 basis of rocket-nuclear "shield" of the USSR. Practical value. Scientific popularization and deepening for the students of higher school, engineering-technical and scientific workers of physical-technical knowledge in area of history of becoming and development in the former USSR of military and peaceful rocket production, extending their scientific and technical range of interests and further development of scientific and technical progress in society. References 24, tables 2, figures 13.

Key words: space-rocket technology, distinguished Soviet designer of space-rocket technology Mikhail Yangel, achievements in a military and peaceful rocket production, scientifically-historical essay.

Наведено науково-історичний нарис про видатного радянського конструктора ракетно-космічної техніки Михайла Кузьміча Янгеля, що став одним 3 творців вітчизняного ракетно-ядерного «щита». Описані основні науково-технічні досягнення М.К. Янгеля в галузі розробки і створення в СРСР бойового стратегічного ракетного озбросння і ракетнокосмічної техніки для мирного освосння космосу. Показано, щзо Головний конструктор ОКБ-586 (КБ «Південне», М. Дніпропетровськ) М.К. Янгель є «батьком» радянських бойових мізкконтинентальних балістичних ракет (МБР) першого (з індексами 8К63, 8К65 і 8К64), другого (з індексами 8К67, 8К69 і 8К67П) та третього (3 індексами 15А14, 15A15, 15 A16 і 15A18) поколінь. При створенні МБР четвертого покоління (з індексами 15А18М, 15Ж60 і 15Ж61) були застосовані його ідеї. Дані бойові МБР забезпечили в період «холодної війни» для СРСР паритет в світовій гонці стратегічних ракетно-ядерних озброєнь. Бібл. 24, табл. 2, рис. 13.

Ключові слова: ракетно-космічна техніка, видатний радянський конструктор ракетно-космічної техніки Михайло Янгель, досягнення у військовому і мирному ракетобудуванні, науково-історичний нарис.

Приведен научно-исторический очерк о выдающемся советском конструкторе ракетно-космической техники Михаиле Кузьмиче Янгеле, ставщем одним из создателей отечественного ракетно-ядерного "щита». Описаны основные научно-технические достижения М.К. Янгеля в области разработки и создания в СССР боевого стратегического ракетного вооружения и ракетно-космической техники для мирного освоения космоса. Показано, что Главный конструктор ОКБ-586 (КБ «Южсное», 2. Днепропетровск) М.К. Янгель является «отцом» советских боевых межконтинентальных баллистических ракет (МБР) первого (с индексами 8К63, 8К65 и 8К64), второго (с индексами 8К67, 8К69 и 8К67П) и третьего (с индексами 15А14, 15А15, 15 А16 и 15А18) поколений. При создании МБР четвертого поколения (с индексами 15А18М, 15 Ж0 и 15Ж61) были применены его идеи. Данные боевые МБР обеспечили в период «холодной войны» для СССР паритет в мировой гонке стратегических ракетно-ядерных вооружений. Библ. 24, табл. 2, рис. 13.

Ключевые слова: ракетно-космическая техника, выдающийся советский конструктор ракетно-космической техники Михаил Янгель, достижения в военном и мирном ракетостроении, научно-исторический очерк.

Introduction. At present, taking into account the past years and declassifying many previously inaccessible to the general reader materials related to the formation and development of the missile industry in the former
USSR, which had important military strategic importance, it is becoming known that the best Soviet intercontinental ballistic missile (ICBMs) were designed and created by 
not the notorious designer of rocket and space technology (Chief Designer of SDB-1, Kaliningrad city, Moscow Region), twice Hero of Labor, academician of the Academy of Sciences of the USSR (since 1958) S.P. Korolev [1], but by the Chief Designer of SDB-586 (Design Bureau «Yuzhnoye» («Southern»), Dnipropetrovsk city) M.K. Yangel [2]. It is M.K. Yangel practically «shouldered» the incredible responsibility and the whole burden of the USSR's defense against a potential nuclear missile strike of the enemy's forces of the West. Merits of S.P. Korolev in the creation of the first Soviet ICBMs, set in 1956-1968 into service with the Strategic Missile Forces, no one pleads. In the competition M.K. Yangel actually «untied» the hands of S.P. Korolev for the Soviet breakthrough into peaceful space. It is required to pay tribute to the fully undervalued in the 20th century bright and successful outstanding Soviet designer of rocket and space technology twice Hero of Labor (1959. 1961), Academician of the Academy of Sciences of the Ukrainian SSR (since 1961) and of the Academy of Sciences of the USSR (since 1966) Mikhail Kuzmich Yangel [2] (Fig. 1). To do this, in the form of a scientific and historical essay about him, we make a modest contribution - we as the heirs of the works of M.K. Yangel.

The goal of the paper is preparation of a brief scientific and historical essay on the outstanding designer of domestic rocket and space technology and one of the main creators of launch vehicles for the Soviet nuclear missile «shield» M.K. Yangel.

1. The beginning of life and career of M.K. Yangel. Mikhail was born on November 7, 1911 in the East Siberian village of Zyryanova (Irkutsk province, Russian Empire) in a large peasant family of Kuzma Lavrentievich and Angelina Petrovna Yangel, who had 12 children [2]. As we see, the name and surname of this man glorified in the future by his titanic work is very associated in human consciousness with the divine word «angel», which was, as it were, sent to earthlings from heaven to comprehend the mysteries of our world.

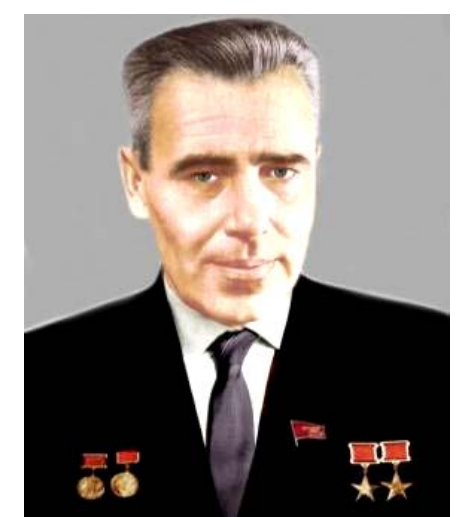

Fig. 1. Outstanding Soviet designer of space and rocket technology, twice Hero of Labor, Lenin Prize Laureate, Doctor of Technical Sciences, Academician of the Academy of

Sciences of the Ukrainian SSR and of the Academy of Sciences of the USSR Mikhail Kuzmich Yangel

$(07.11 .1911-25.10 .1971)$ [2]

In 1926, after finishing the sixth grade of a village school, he moved to Moscow to his older brother
Konstantin [2]. After graduating from a factory school, in the period 1929-1931 Mikhail works as an assistant craftsman at a textile factory (Krasnoarmeysk, Moscow region). In 1931 he entered the Moscow Aviation Institute, which in 1937 he graduated with honors in the specialty «Aircraft Engineering» [2]. In the period 19351944 he worked in various positions (starting with the leading engineer and ending with the Director) at the plant-branch at the Design Bureau, led by the famous Soviet aircraft designer N.N. Polikarpov [3]. He participated in the development and refinement of his combat fighter aircrafts I-153, I-180 and I-185 [2]. In 1944 he was Deputy Chief Engineer of the aircraft plant No. 155 at the experimental design bureau (EDB), headed by prominent in the future aircraft designer A.I. Mikoyan, and in 1945 he began to work as a leading engineer at the design bureau of the famous Soviet aircraft designer V.M. Myasishchev [2]. In the period 1946-1948, while working at the special department of the Ministry of Aviation Industry of the USSR, he coordinated work both in the field of domestic aircraft construction and the work of numerous talented Germans-rocket men moved from Germany to the USSR [1]. These two years of communication with German rocket experts and the study of captured documents from Germany in the field of rocketry gave much to M.K. Yangel in understanding the ways of formation of the missile industry in the USSR. In 1950, he graduated with honors from the USSR Academy of Aviation Industry. Since April 12, 1950 (the future Cosmonautics Day of the USSR), its official «entry» into the rocket industry of our country begins [2, 4]: first, he holds the position of Head of Department at SDB-1 (Kaliningrad city, Moscow Region), created at the leading institution of the USSR in the field of rocket science SRI88 [1] and led by S.P. Korolev, and then since 1951 he became one of the Deputy Chief Designers of S.P. Korolev. In May 1952, he was appointed as Director of the leading research institute SRI-88 in the USSR, which included 25 Departments, a pilot plant, two branches and more than ten Design Bureaus, including SDB-1 of extremely ambitious and striving for its own one-man management in the missile industry of the USSR S.P. Korolev. Apparently, by so high appointment of M.K. Yangel, to whom S.P. Korolev had to obey, the wise Soviet leadership (first of all, represented by the Minister of Arms of the USSR, then Colonel-General D.F. Ustinov, who later became the Marshal of the USSR, three times Hero of Labor and the USSR and who had the largest number of orders of Lenin in our country - 10 [5]) sought to limit the rocket «monopoly» of S.P. Korolev. We indicate that the Chief Designer of SDB-1 S.P. Korolev showed himself not in the best circumstances for him $[6,7]$ : he defiantly did not attend the meetings held by his boss M.K. Yangel, often ignored the orders of the new Director of SRI-88 and, with great delays, carried out his decisions. It was from this period that the «difficult» personal and generally difficult relationships began between these legendary Soviet rocket designers. Understanding the situation, M.K. Yangel in October 1953 made an extraordinary decision - he submitted to his Minister an application to dismiss him from the post of Director of SRI-88 of his own free will. In November 
1953, by the order of the indicated Minister D.F. Ustinov, he was dismissed from the post of Director and appointed as Chief Engineer of SRI-88. In such a way M.K. Yangel after fulfilling administrative duties again found himself in his native creative «environment»: he had the opportunity to develop a new direction in rocket science and technology - the use of high-boiling fuel components and an autonomous control system in ICBMs. At this time the «outcome» took place of persons who many did during the period 1945-1954 under the leadership of Wernher von Braun's colleague Helmut Gröttrup's leadership to lift Soviet rocketry technology of Russified German missile-rocket experts from the USSR to the German Democratic Republic [1].

2. The main achievements of M.K. Yangel in military rocketry (1954-1971). In April 1954, a Special Decree of the Council of Ministers of the USSR established the Special Design Bureau No. 586 (SDB586, which became known as the Design Bureau «Southern» in 1966) on the basis of a serial rocket plant No. 586 (Dnepropetrovsk city), and M.K. Yangel was appointed as its Head and Chief Designer [7]. The main activity of M.K. Yangel and the SDB-586 headed by him has been developing and creating Soviet combat ICBMs. Work in the field of creating spacecrafts and the peaceful exploration of outer space was in the background for him. The first for M.K. Yangel missiles were rockets of medium (P-12) and medium (P-14) range [7, 8]. On June 22,1957 , the first and successful test was conducted at the Kapustin Yar training ground for the P-12 rocket that he created (in NATO terminology SS-4, Fig. 2) [9].

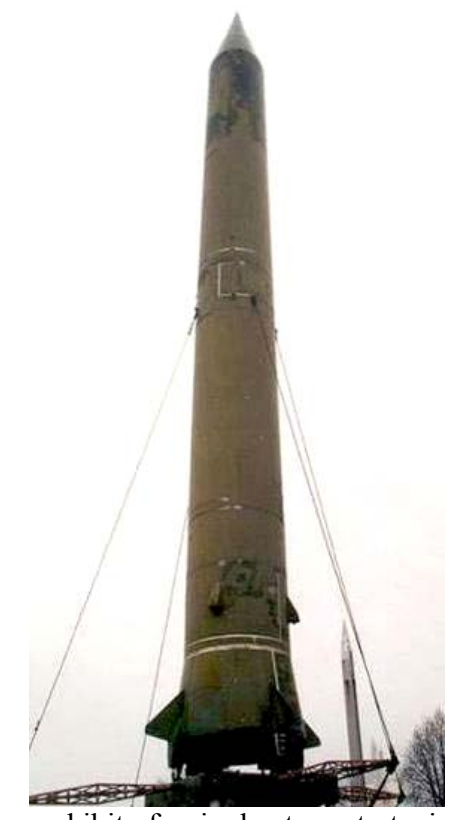

Fig. 2. Museum exhibit of a single-stage strategic missile of type P-12 (military index 8K63) on the launch pad (1957, chief designer - M.K. Yangel) [9]

Table 1 shows the main tactical and technical characteristics of the rocket of type P-12 (8K63), created in SDB-586 under the leadership of M.K. Yangel. This single-stage rocket with liquid high-boiling fuel was the first strategic missile developed at SDB-586 (Dnepropetrovsk city) [9, 10].
Table 1

The performance characteristics of the Soviet combat missile P-12 (8K63) with a thermonuclear charge [9]

\begin{tabular}{|c|l|c|}
\hline No. & \multicolumn{1}{|c|}{ Name of characteristic } & Value \\
\hline 1 & Body length, $\mathrm{m}$ & 21.1 \\
\hline 2 & Case diameter, $\mathrm{m}$ & 1.65 \\
\hline 3 & Starting weight, $\mathrm{t}$ & 41.7 \\
\hline 4 & Number of stages & 1 \\
\hline 5 & TNT warhead mono-charge power, Mt & 2.3 \\
\hline 6 & Range of flight (firing), km & 2080 \\
\hline \multirow{2}{*}{7} & $\begin{array}{l}\text { High boiling rocket fuel components: } \\
\text { - brand of fuel }\end{array}$ & TМ-185 \\
& - brand of oxidizing agent & $1959-$ \\
\hline \multirow{2}{*}{8} & $\begin{array}{l}\text { Period of being in service with the } \\
\text { Strategic Missile Forces of the Soviet } \\
\text { Army }\end{array}$ & 1988 \\
\hline
\end{tabular}

Note that on the basis of the P-12 strategic missile (see Fig. 2), related to the first generation combat missiles and intended for ground launch, the SDB-586 developed the P-12Y missile (military index $8 \mathrm{~K} 63 \mathrm{Y}$ ) with increased nuclear resistance blows of the probable opponent, intended for a mine start. Note that compared to the first rocket of type P-1 of S.P. Korolev [1], which was an exact copy of the German single-stage V-2 with liquid rocket engine (LRE) [11], the first P-12 rocket of M.K. Yangel produced in the amount of 2300 pcs and had been on combat duty for about 30 years [9], with almost the same diameter and greater length of the hull 1.5 times had a range of flight (firing) of about 7 times greater. The main reason for this was that the LRE of the P-1 rocket and all subsequent missiles of S.P. Korolev worked on lowboiling fuel (kerosene) with a liquid-oxygen oxidizer, and the rocket engines of all M.K. Yangel's rockets - on highboiling fuel with new types of oxidizing agents. This was followed by work on the creation of the P-14 (8K65) missile with a firing range twice as large as that of the P12 missile. The features of the P-14 rocket (in NATO terminology SS-5) were [10]: firstly, the use of НДМГ fuel; secondly, the use of a gyro-stabilized platform for an autonomous inertial missile control system, which allows to reduce instrumental errors in the control system and to provide higher accuracy of its fire. In June 1960, the first successful launch of the intermediate-range missile (up to $4000 \mathrm{~km}$ ) P-14, developed by the SDB-586, was carried out according to the program of its flight design tests [10].

The legislative bodies of the USSR set for M.K. Yangel (Fig. 3) and his SDB-586 a new important task: the development of the ICBM project on high-boiling and long-stored fuel components. Such a missile became the P-16, which was created in a fairly short time. Preparation for the first launch of which on October 24, 1960 ended with the largest disaster in the history of domestic rocket science [10]. Then, during pre-launch work (about 15 minutes before the scheduled test launch of the first M.K. Yangel's ICBM), an unauthorized start of the secondstage engines of this ICBM occurred and the P-16 rocket (in NATO terminology SS-7) exploded right on the launch pad site of the Baikonur training ground [12]. In a fiery tornado, diverging in concentric waves from the launch center to a distance of up to $120 \mathrm{~m}, 76$ people were immediately burned alive. Among them were [2, 12]: 
commander of the Strategic Missile Forces of the USSR, Artillery Marshal M.I. Nedelin, chief designers of rocket systems, testers, militants and employees of a number of design bureaus. Subsequently, 16 more people died in hospitals due to burns and poisoning [12].

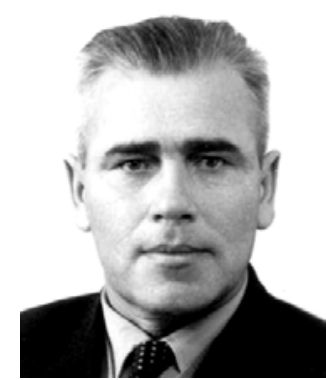

Fig. 3. Chief designer of the Soviet SDB-586, which in 1966 became known as the Design Bureau «Southern»

(Dnepropetrovsk city), M.K. Yangel at the «zenith» of the heyday of design talent and creative work in the development and creation of powerful domestic military ICBMs with LRE (photo of the 1950s) [7]

Chief Designer M.K. Yangel miraculously survived this disaster: he and several other people, a few minutes before the explosion of the $\mathrm{P}-16$ rocket, moved away from the place where it started to smoke [2, 12]. Mikhail Kuzmich hard endured this tragedy, which hit us hard, as they say, directly «under the breath» of the SDB-586 and its team. The tasks of strengthening the country's defense required the completion of work on the P-16 (8K64) missile. On February 21, 1961, the first successful launch of the P-16 (SS-7) ICBM, related to first-generation combat missiles, was carried out in the USSR [10, 12]. ICBM R-16 in front of all ICBMs of S.P. Korolev had a number of advantages [12]: firstly, it was refueled with new fuel components, which enabled it to be in a refilled state for up to 30 days, and then more; secondly, the rocket had an autonomous control system leading the P16 to the target without any connection with the Earth; thirdly, it was easier to operate. Later, this missile was adopted and it formed the basis of the Strategic Missile Forces of the USSR.

In the early 1960s, the SDB-586 was actively engaged in the modernization of first-generation strategic combat missiles [13]: their main focus was the ampouled execution of the fuel tanks of the missiles and the possibility of their being in the refueled state for up to seven years. At this time, in the USA, a Titan-2 minebased ICBM was created based on high-boiling fuel, capable of carrying a thermonuclear charge of high power. There were no such ICBMs in the USSR at that time. In this regard, the main Soviet missile design bureaus received from the country's legislative bodies tasks for the development of powerful missiles of heavy and superheavy classes. To achieve these goals, the SDB586 proposed a project of a middle-class missile implemented in the P-36 missile system (military index $8 \mathrm{~K} 67$, in NATO terminology SS-9) in ballistic and orbital versions of missiles [13]. On September 28, 1963, the first and successful launch of the P-36 rocket, belonging to the second generation of combat missiles, was carried out. Further, under the leadership of M.K. Yangel the SDB-586 creates an orbital ICBM with a military index of 8K69 [13]. This class of ICBMs had a unique property: with an unlimited range of fire, it can deliver a warhead for the defended state from two directions - from the front and rear, which forced the probable enemy to create missile defense on their borders simultaneously from two directions. Technically, this property was provided by a specific flight pattern of an orbital rocket along flat trajectories, including the trajectory of an artificial Earth satellite (AES) [13]. In December 1965, the first launches of such an orbital Soviet missile were carried out according to the program of its flight design tests. In August 1968, a new powerful ICBM of the second generation of SDB-586 development missiles, a missile with a military index of $8 \mathrm{~K} 67 \Pi$, which is a modification of P-36 type ICBM with a military index of $8 \mathrm{~K} 67$ and having a three-part warhead that is divided in flight, was launched from a Soviet test site [13]. In the period 19641980, 288 units were deployed in the USSR of the heavy P-36 ICBMs (SS-9 missiles, which were in 1965 the most powerful military missiles in the world with thermonuclear charges) with a launch weight of 183 tons and a warhead weight of 5.8 tons $[12,14]$.

In the late 1960s, the USSR experienced a quantum leap in the creation of strategic missile systems. The efforts of many domestic research institutes and design bureaus have developed reliable small-sized on-board digital computers, high-precision command instruments of missile control and aiming systems, thermonuclear charges with high specific combat characteristics, more advanced rocket propulsion systems, new schemes and methods of hardening launchers [15]. This became the basis for the creation of third-generation combat ICBMs. One of the main features of the third generation of military missile equipment of the USSR was the use of a «mortar launch» of missiles from a transport and launch container (TLC) [15]. With this type of launch, the rocket, due to the triggering of the powder charge installed in the lower part of the TLC (Fig. 4), flew out of the container (figuratively for the reader we say like a cork from a bottle of champagne), and then its rocket engines were launched in flight of the rocket outside the container. Decision of M.K. Yangel about the transition to this type of launch of ICBMs was so new and unusual that for many of his colleagues from SDB-586 it seemed simply fantastic and risky.

On September 2, 1969, the USSR Council of Ministers issued a secret decree «On the development and manufacture of the P-36M (15A14) missile system» (now it has been declassified), aimed at creating at Design Bureau «Southern» (successor since 1966 to the legendary SDB-586) of the combat heavy missile complex P-36M (military index 15A14, according to NATO terminology SS-18 «Satan») instead of a heavy ICBM of type P-36 (military index 8K67, SS-9) [14]. 


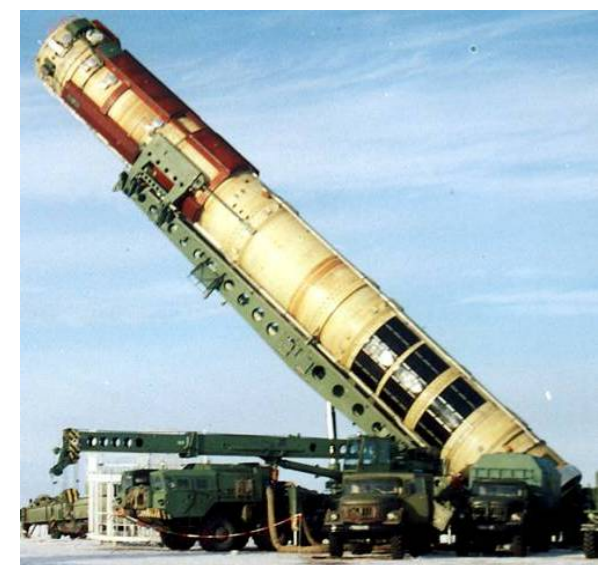

Fig. 4. Moment of loading of heavy combat ICBM of type P-36M (military index 15A14, in NATO terminology SS-18

«Satan»), placed in a massive fiberglass TLC, in the mine launcher (1978) [14]

The preliminary design of the Soviet two-stage heavy missile P-36M (15A14), carried out under the leadership of M.K. Yangel, was completed in record time - in December 1969 [14]. At the first stage of the P-36M rocket, a block of four-chamber closed-circuit LREs was used, and at the second stage, a single-chamber march closed-circuit LRE and four-chamber open-circuit steering LRE [14]. The composition of the separable warhead (SWH) of the P-36M (15A14) rocket included eight individual guidance (IG) units with thermonuclear charges [14]. The use of a more advanced design (lightweight units and their tight layout) and more efficient closed-circuit rocket engines in heavy combat ICBM P-36M allowed, with almost the same dimensions as of the combat ICBM P-36, to increase the launch mass of the missile to $209.6 \mathrm{t}$ with a weight of its head part (HP) up to $8.8 \mathrm{t}$ [14]. This missile was located in a thickwalled fiberglass TLC (see Fig. 4), which was installed in a converted mine launcher (ML) from the P-36 missile. The ML of a combat P-36M ICBM was a structure with a vertical barrel depth of $39 \mathrm{~m}$ and a diameter of $5.9 \mathrm{~m}$ and was distinguished by increased security and resistance to a nuclear strike by a likely enemy (Fig. 5) [14]. Figure 6 shows a general view of the museum exhibit of the Soviet heavy combat missile of the P-36M type, developed and created at the Design Bureau «Southern» (Dnepropetrovsk city) under the leadership of the Chief Designer M.K. Yangel [14-16].

Figure 7 captures the mine launch of the Soviet combat two-stage heavy ICBM of the P-36M type (military index 15A14, in NATO terminology SS-18 «Satan»), created at the Design Bureau 'Southern» [14].

Table 2 shows the tactical and technical characteristics of the Soviet combat ICBM P-36M (15A14) [14].

We point out that in January 1971 «throw» tests of the P-36M (15A14) missile were launched, during which its «mortar launch» was being worked out [14]. On February 21, 1973 (at that time the student and associate of M.K. Yangel, Academician of the Academy of Sciences of the Ukrainian SSR (since 1976) and of the Academy of Sciences of the USSR (since 1984), an outstanding scientist and designer of rocket and space technology, twice Hero of Labor $(1969,1976)$ V.F. Utkin [17] became the Director and General Designer of the Design Bureau «Southern»;) flight design tests of the new P-36M (15A14) rocket complex began [14].

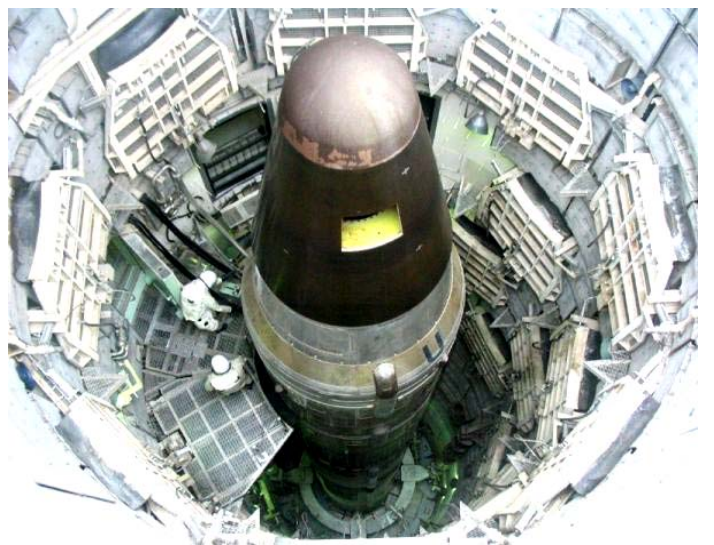

Fig. 5. General view of the ML with the Soviet P-36M type ICBM installed in it (military index 15A14, SS-18 «Satan») during maintenance of the missile by military personnel from folding platforms [14]

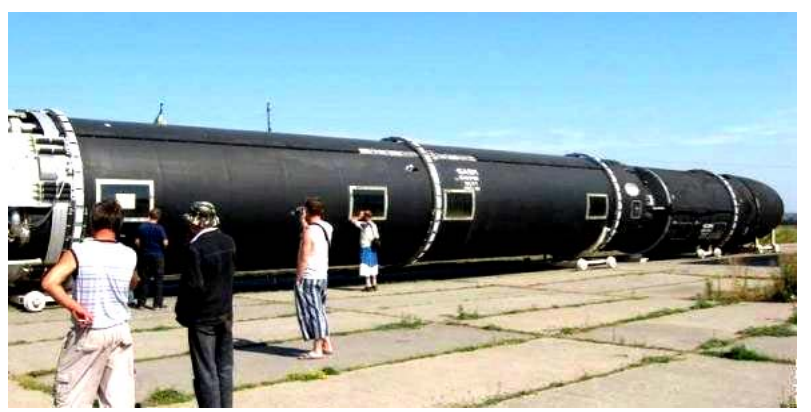

Fig. 6. General view of the museum exhibit of the Soviet military two-stage heavy ICBM of type P-36M (military index

$15 \mathrm{~A} 14$, SS-18 «Satan»), which became the most powerful strategic missile in the world in the 1970s [14]

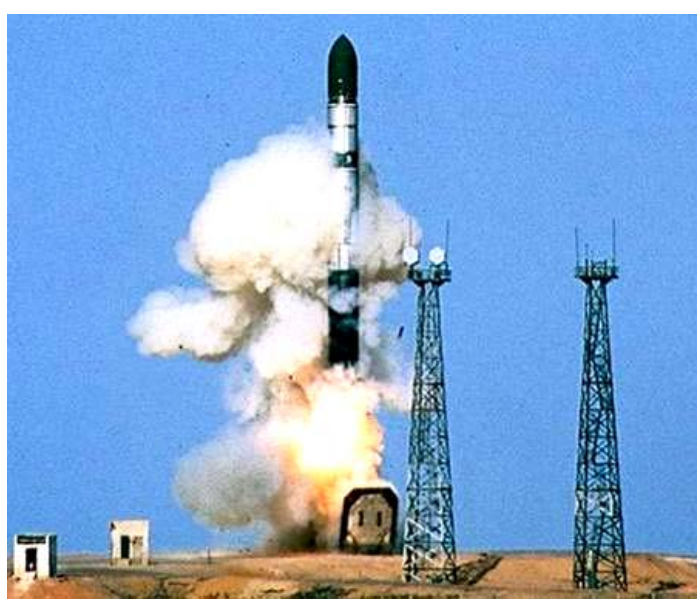

Fig. 7. Moment of «mortar launch» from the ML of the Soviet military two-stage heavy ICBM of type P-36M (military index $15 \mathrm{~A} 14$, in NATO terminology SS-18) [14]

Note that the tests of this complex with three types of combat equipment were completed in October 1975, and on December 30, 1975 the Soviet heavy P-36M ICBM (military index 15A14, in NATO terminology SS18 «Satan») was adopted by the Strategic Missile Forces of the USSR [14]. 
Table 2

The performance characteristics of the Soviet combat heavy ICBM P-36M (15A14, SS-18 «Satan») [14]

\begin{tabular}{|c|c|c|}
\hline No. & Name of characteristic & Value \\
\hline 1 & Body length, $\mathrm{m}$ & 36.6 \\
\hline 2 & Case diameter, $\mathrm{m}$ & 3.0 \\
\hline 3 & Starting weight, $\mathrm{t}$ & 209.6 \\
\hline 4 & Number of stages & 2 \\
\hline 5 & $\begin{array}{l}\text { Charge power of the warhead in TNT } \\
\text { equivalent, performed in four versions } \\
\text { (monoblock: Mod } 1 \text { or Mod 2; SWH } \\
\text { with IG: module } 3 \text { or module } 4 \text { ), kg }\end{array}$ & $\begin{array}{l}\text { Module 3: } \\
\text { SWH IG } \\
8 \times 900 \mathrm{~kg} \text {; } \\
\text { Module 4: } \\
\text { SWH IG } \\
8 \times 750 \mathrm{~kg}\end{array}$ \\
\hline 6 & Range of flight (firing), km & $\begin{array}{l}16000 \text { (light } \\
\text { HP); } \\
-11200 \\
\text { (heavy HP); } \\
-10200 \text { (SWH } \\
\text { with IG) } \\
\end{array}$ \\
\hline 7 & $\begin{array}{l}\text { High boiling rocket fuel components: } \\
\text { - brand of fuel: } \\
\text { - brand of oxidizing agent: }\end{array}$ & $\begin{array}{l}\text {-Asymmetric } \\
\text { dimethylhyd } \\
\text { razine } \\
(\mathrm{ADMH}) \text {; } \\
\text {-Diazot } \\
\text { tetraoxide } \\
\left(\mathrm{N}_{2} \mathrm{O}_{4}\right) .\end{array}$ \\
\hline 8 & Fuel weight, t & 188.0 \\
\hline 9 & Missile control system & $\begin{array}{l}\text { Autonomous } \\
\text { inertial }\end{array}$ \\
\hline 10 & $\begin{array}{l}\text { Thrust force of the first stage LRE, } \\
\mathrm{kN}\end{array}$ & $\begin{array}{l}-4163 \text { (at sea } \\
\text { level); } \\
-4520 \text { (in } \\
\text { vacuum). }\end{array}$ \\
\hline 11 & $\begin{array}{l}\text { Mass of the warhead } \\
\text { of the missile, } t\end{array}$ & 8.8 \\
\hline 12 & $\begin{array}{l}\text { Specific impulse of the first stage of } \\
\text { the missile, } \mathrm{m} / \mathrm{s}\end{array}$ & $\begin{array}{l}-2874 \text { (at sea } \\
\text { level); } \\
-3120 \text { (in } \\
\text { vacuum). }\end{array}$ \\
\hline 13 & Missile launcher type & $\begin{array}{l}\text { ML with } \\
\text { «mortar } \\
\text { launch» }\end{array}$ \\
\hline
\end{tabular}

Unfortunately, this day did not wait for our great designer of military rocketry, twice Academician (of the Republican and the Soviet Union's Academies of Sciences) M.K. Yangel, who died on October 25, 1971 in Moscow from another heart attack [2]. The Soviet combat heavy ICBM of type P-36M (15A14, SS-18 «Satan») was a triumph of the design talent of our compatriot M.K. Yangel. He created it not for attacking and destroying people, but for the sake of the survival of mankind in the frenzied nuclear arms race that has swept our entire world. And how many were in the USSR at the beginning of its development of opponents of this grandiose missile project? Even long-time associate of M.K. Yangel, chief designer of the Soviet ML E.G. Rudyak proved that the design of the P-36M (15A14) missile at its «mortar launch» [12] was inconsistent: «... To throw, like an apple, a liquid colossus weighing more than two hundred tons is pure absurdity». But M.K. Yangel turned this absurdity into a reality. By 1988, almost half of all thermonuclear warheads of the Strategic Missile Forces of our country were located in the USSR on this legendary ICBM [12].
Later, at the $\mathrm{Db}$ «Southern», taking into account the ideas and developments of M.K. Yangel, improved ICBMs of the third generation of mine military missiles [15] were developed: P-36M YTTX missile systems (military index 15A18) equipped with SWH with 10 IG combat units, and MP-YP100 missile systems (military index 15A15, Fig. 8) and its improved version MP-УP100 YTTX (military index 15A16), equipped with SWH with four IG combat units. In these developments of the ICBMs, all the achievements of Soviet science and missile technology available at that time were embodied. For M.K. Yangel work on the Soviet strategic missile systems P-36M (15A14, SS-18) and MP-YP100 (15A15, SS-17) became the «swan song». By the way, it took the United States five years for the practical implementation of the «mortar launch» after the USSR from the buried mines of its strategic ballistic missiles [14, 15].

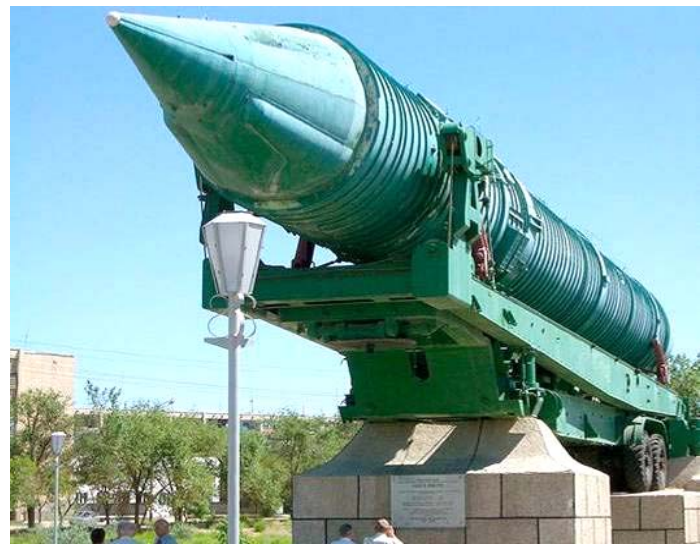

Fig. 8. General view of the museum exhibit of the Soviet ICBM MP-YP100 (military index 15A15, in NATO terminology SS-

17) with TLC developed and created at the Design Bureau «Southern» [18]

To complete the «picture» of the achievements of the DB «Southern» in the field of creation in the period 1980-1991 (at that time, its Directors and General Designers were already mentioned V.F. Utkin and a talented student of M.K. Yangel and V.F. Utkin, a famous Ukrainian designer of rocket and space technology, Doctor of Technical Sciences, Academician of the NAS of Ukraine (since 1992), Hero of Ukraine (2004) S.N. Konyukhov [19]) of high-performance powerful ICBMs of the fourth generation of combat missiles, we note that during their development the main areas of work were [20]: firstly, the creation of missiles capable of starting directly under the conditions of a nuclear strike on a positional area; secondly, the creation of mobile-based solid-fuel rockets, the survivability of which is achieved due to their mobility and uncertainty of location. Both of these areas were implemented in the P-36M2 «Voyevoda» missile systems (military index 15A18M, in NATO terminology SS-18-3) developed by the Design Bureau «Southern» with LRE of fixed-mine base and solid-fuel ICBMs of the PT-23 and PT-23 УTTX «Molodets» type (military indices $115 Ж 60$ и 15Ж61, in NATO terminology SS-24-1 and SS-24-2) of a mine and mobile railway base [20]. The scientific basis for the creation of these Soviet mobile missile systems was laid by the perspicacious and talented M.K. Yangel. With the 
collapse of the USSR, work on the development and creation of new strategic missile systems at the Design Bureau «Southern» was discontinued [20].

3. The main achievements of M.K. Yangel in rocket and space technology for peaceful purposes (1961-1971). Note that in the field of creating spacecrafts (SCs) M.K. Yangel also achieved considerable success. Of particular interest here is the fact that M.K. Yangel, despite the «difficult» relationships with the Chief Designer of SDB-1 S.P. Korolev, took an active share in the 1960s in the creation in the USSR of a super-heavy launch vehicle of the H-1 type, designed for the flight of a Soviet manned spacecraft to the Moon [1]. M.K. Yangel had his own achievements in creating a similar P-56 launch vehicle (launch weight up to 1200 tons) at the SDB-586, which had only four LREs with a thrust of 640 tons each in its first stage [2]. In the design of the H-1 launch vehicle (Chief Designer - S.P. Korolev), 30 lowpower LREs, operating simultaneously with kerosene and liquid oxygen, were to be installed at the first stage [2]. Further events in the implementation of the Lunar Program of the USSR showed that the wrong approach of S.P. Korolev to the choice of the type of the LRE for the first stage of the H-1 launch vehicle led to its explosion on the launch pad and the destruction of the launch complex. Accept S.P. Korolev position of M.K. Yangel, perhaps the Soviet cosmonaut would have entered the first in the history of mankind on the surface of the Moon. However, designed, manufactured and tested under the guidance of M.K. Yangel in low Earth orbit, the lunar module by the SDB-586 of the project H-1 - Л3 (block «E») was the only one in the USSR that was completely ready for space flight in the framework of the Soviet Lunar SC program [2]. As we can see, these data additionally emphasize the originality of the personality and the versatility of scientific and engineering talent of M.K. Yangel, who always sought to adapt and modify combat launch vehicles for their use in the peaceful exploration of outer space. The constantly growing needs of the regular launch in the USSR into orbits of satellites for various purposes made it necessary to refine the P-14 (8K65) combat missile at the SDB-586 with a view to using it as a space launch vehicle. Thus, the Space-1 launch vehicle was created [7]. On the basis of the twostage combat rocket P-36 (8K67), the Space-2 space launch vehicle was developed [7]. The first launch of the Space-2 launch vehicle was carried out on August 18, 1964. A total of 700 launches of the Space-2 launch vehicle were made, which launched more than 1000 different spacecrafts into orbit. On the basis of the $8 \mathrm{~K} 69$ military missile at the Design Bureau «Southern», the Cyclone-2 launch vehicle was created (Fig. 9), designed to launch military and civil spacecrafts into low circular and elliptical near-earth orbits $[7,16]$.

We point out that the first launch of the Cyclone-2 launch vehicle (Chief Designer - M.K. Yangel) took place on August 6, 1969 from the Baikonur Cosmodrome (Kazakhstan), and the last one in June 2006 [4]. Having finalized the powerful 8K69 military missile, the Design Bureau «Southern» created a three-stage Cyclone-3 launch vehicle. Its first launch with the SC took place from the Plesetsk Cosmodrome (RF) on June 24, 1977, and the last one in January 2009.

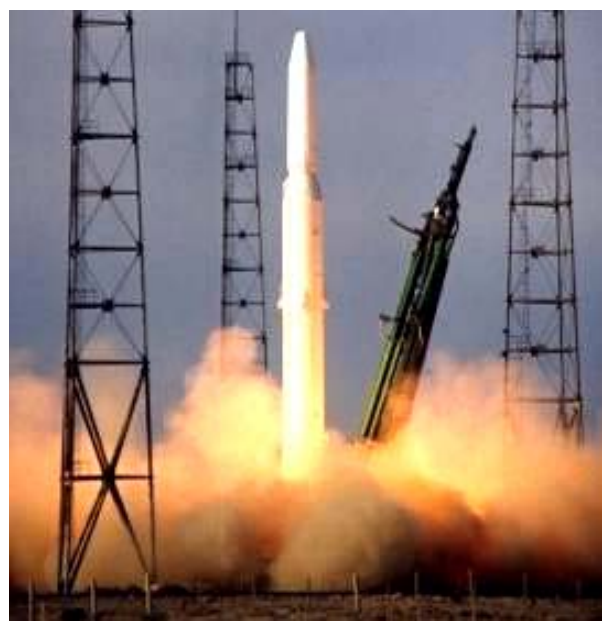

Fig. 9. Launch moment of the Cyclone-2 launch vehicle [4]

In May 1939, Irina Viktorovna Strazheva (Fig. 10) became the wife of the outstanding designer of space and rocket technology M.K. Yangel [7, 8]. In their family, a daughter Lyudmila and a son Alexander were born. I.V. Strazheva became a Doctor of Technical Sciences and worked as a Professor at the Moscow Aviation Institute (MAI) [2]. Note that since the end of the 1960s, the Chief Designer of Design Bureau «Southern» began to live in a service house. Before that, he lived for 12 years in a hotel in Dnepropetrovsk, and later in a small two-room apartment with the family of his son Alexander.

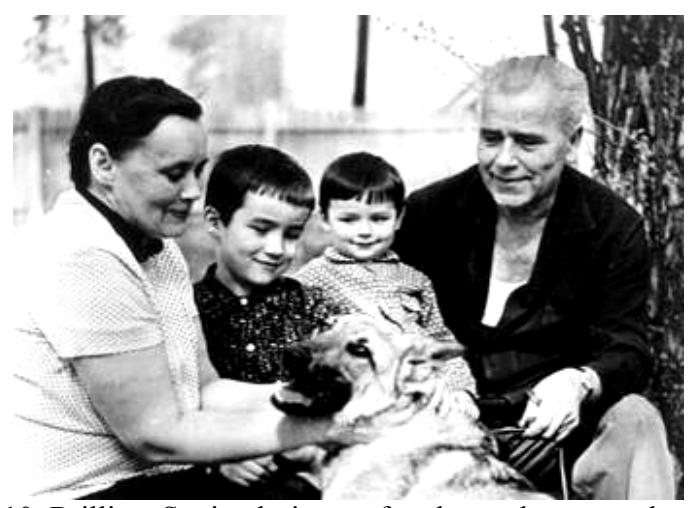

Fig. 10. Brilliant Soviet designer of rocket and space technology M.K. Yangel with his wife I.V. Strazheva, the grandchildren Dima and Seryozha (the children of their daughter Lyudmila) during their common summer vacation at Mikhail Kuzmich's

cozy summer house near Moscow (1967, settlement of Barvikha, RF) [8]

4. Awards, distinctions and recognition of the merits of M.K. Yangel. This great designer in the field of rocket science and an aeromechanic scientist was awarded the following Soviet state awards and was awarded such honorary titles [2]:

- two gold medals of the Hero of Labor «Hammer and Sickle» $(1959,1961)$;

- four Orders of Lenin $(1956,1959,1961,1969)$;

- Laureate of the Lenin Prize (1960);

- Laureate of the USSR State Prize (1967); 
- Academician of the Academy of Sciences of the Ukrainian SSR (1961);

- Academician of the Academy of Sciences of the USSR (1966);

- S.P. Korolev gold medal of the Academy of Sciences of the (1970);

- Order of the October Revolution (1971);

- Medal «For the Defense of Moscow» (1944);

- Honorary resident (citizen) of Baikonur.

President of Ukraine (in the period 1994-2005) L.D. Kuchma, who once worked as the Director of the «Yuzhmash» plant and had close contact with the Design Bureau «Southern» under the leadership of M.K. Yangel, as his grateful follower said [2]: «... Yangel is a fantastically talented scientist and designer. Yangel lived without sparing himself. He lived without looking back, burning his life «fuel». For months and years at spaceports - in the uninhabited steppe and taiga». The great designer of rocket and space technology died in Moscow from the fifth heart attack on the anniversary of his 60th Birthday - on October 25, 1971. He was buried with the required honors in Moscow at the Novodevichy cemetery (Fig. 11) [21]. Later, along with Mikhail Kuzmich, his son Alexander (in 1989) and his wife I.V. Strazheva (in 1995) were buried. As a result, the tombstone of M.K. Yangel and his relatives, in my opinion, began to emphasize the post-mortem family unity and objectivity took place in the intense life of this outstanding design scientist, the separation and simultaneity of his faithful service to both his family and two fraternal peoples - Russian and Ukrainian. I hope that with this argument the author did not violate not only the sculptor's intention, but also the peace of the deceased.

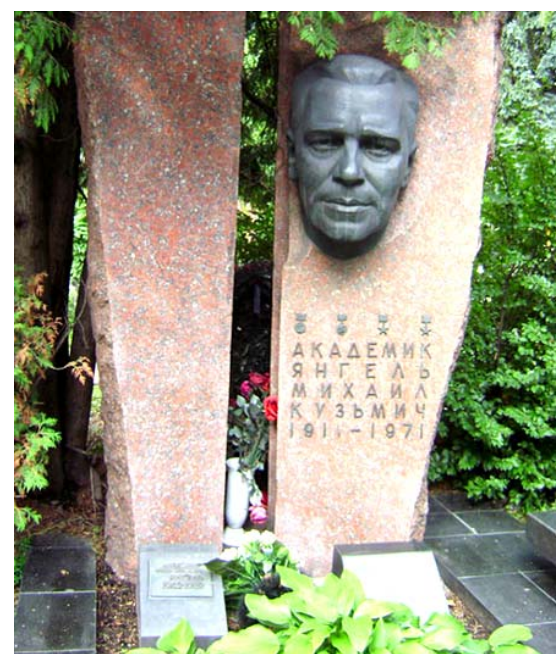

Fig. 11. Tombstone to the great Soviet designer of rocket and space technology, twice Hero of Labor M.K. Yangel (Novodevichy cemetery, Moscow) [21]

In 1991, to commemorate the great merits of the former Director and Chief Designer of the legendary SDB-586, Mikhail Kuzmich Yangel, to the national rocket science, his name was given to the State Enterprise DB «Southern» [2]. On the territory of the huge plant «Yuzhmash» and Design Bureau «Yuzhnoye» («Southern») named after M.K. Yangel a monument to the great domestic scientist-mechanic and designer of rocket and space technology M.K. Yangel (Fig. 12) who forever is in the «battle formation» of the illustrious team of the world leader in the development and creation of modern rocket technology was erected [22].

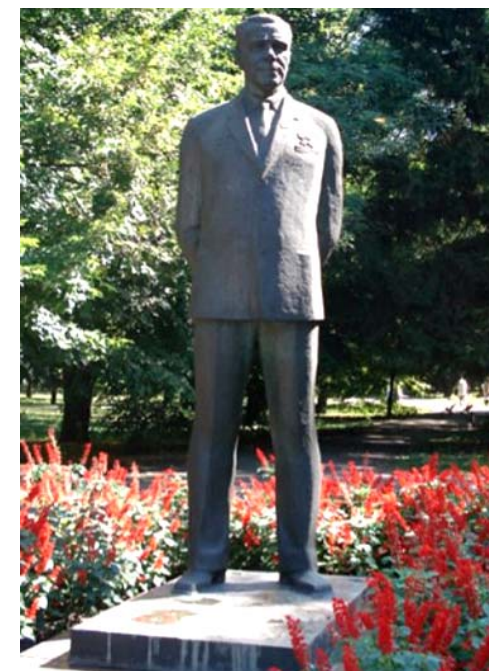

Fig. 12. Monument to the outstanding Soviet scientistaeromechanics and Chief Designer of rocket and space technology M.K. Yangel installed in the territory of the «Yuzhmash» plant and the State enterprise Design Bureau «Yuzhnoye» («Southern») (1991, Dnepropetrovsk, Ukraine) [22]

Commemorative busts were installed in the city of Dnepropetrovsk and the city of Baikonur to the creator of the formidable Soviet survival rocket weapon [23]. Streets in Moscow, Kiev, Dnepropetrovsk, Baikonur, Vinnitsa and Bratsk were named after him [2]. Name of M.K. Yangelya was worn by the Kharkiv Institute of Radio Electronics (in the period 1982-1993). In the name of M.K. Yangel an asteroid, a crater on the Moon, a village in the Irkutsk region, a mountain peak in the Pamirs and an ocean cargo ship of the Russian Federation were named [2]. The Cosmonautics Federations of the USSR (RF) and Ukraine instituted medals named after him. Plaques in his honor now adorn the brick walls of the buildings of the State Enterprise Design Bureau «Southern» (Dnipro city, the former city of Dnepropetrovsk), CNIIMach (former SRI-88, the city of Korolev, Moscow Region) and the Moscow Aviation Institute (MAI, Moscow) (Fig. 13) [24].

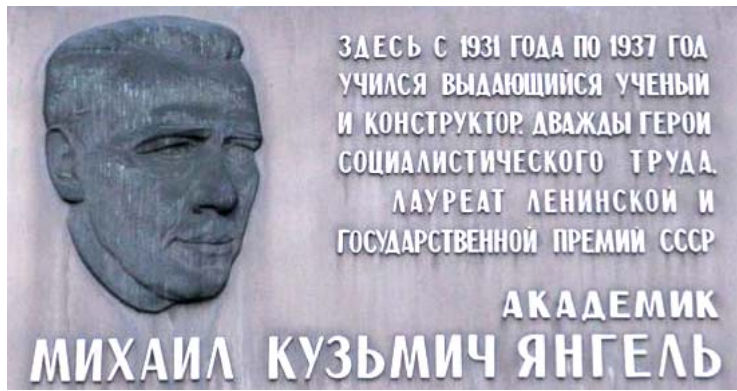

Fig. 13. A memorial plaque on the building of the MAI, where his famous student of aircraft engineering, future Academician and outstanding Soviet designer of rocket and space technology M.K. Yangel studied (Moscow, RF) [24]

Conclusions. An outstanding Soviet scientistaeromechanic and designer of dual-use rocket technology, 
twice Hero of Labor, Academician of the Academy of Sciences of the Ukrainian SSR and of the Academy of Sciences of the USSR Mikhail Kuzmich Yangel made an invaluable contribution to strengthening the defense of the USSR during the Cold War. Under his scientific supervision, at the legendary SDB-586 (Design Bureau «Southern», Dnepropetrovsk city), highly effective combat intercontinental ballistic missiles were developed and created that formed the basis of our country's nuclear missile «shield». He went down in the history of world rocket science as the Chief Designer of the world's most powerful combat ICBM of the P-36M type (military index 15A14, according to NATO terminology SS-18 «Satan»), which carries huge thermonuclear charges in its divided warhead with individual guidance. The adoption in the USSR strategic missile forces of these powerful military intercontinental ballistic missiles with a firing range of (10.2-16) thousand $\mathrm{km}$ immediately «cooled» the hot heads of the militant forces representatives of the West and forced them to significantly reduce offensive nuclear weapons. Thanks to the titanic work of the Special Design Bureaus, which worked well in the USSR, including SDB-586, headed by M.K. Yangel, and the military industries, in the period 1960-1990 for the Soviet country parity in powerful nuclear missile weapons of enormous destructive power was provided. The present generations of grateful people of the planet are in eternal spiritual and moral debt to such bright and talented representatives of the human race as M.K. Yangel, who voluntarily gave themselves to the Altar of the Fatherland and laid down their lives for the sake of maintaining peace on Earth.

\section{REFERENCES}

1. Baranov M.I. An anthology of the distinguished achievements in science and technique. Part 51: Rocket-space technology designer Sergey Korolev and his accomplishments in missile design. Electrical engineering \& electromechanics, 2019, no.5, pp. 3-11. doi: 10.20998/2074-272X.2019.5.01.

2. Available at: https://en.wikipedia.org/wiki/Mikhail_Yangel (accessed 12 June 2017).

3. Available

at:

https://www.google.com/search?q=Авиаконструктор+оликарп oB\&ie $=$ utf- $8 \&$ oe $=$ utf- $8 \&$ client $=$ firefox-b $\quad$ (accessed 11 May 2018).

4. Available

https://www.yuzhnoye.com/company/history/yangel.html (accessed 12 June 2017). (Rus).

5. Available at: https://www.mmsk.ru/people/unit/?id=46786 (accessed 12 September 2018). (Rus).

6. Gubarev V.S. Neskol'ko stranits iz zhizni Mikhaila Kuz'micha Iangelia [Designer. A few pages are from life of Mikhail Kuz'mich Yangel]. Moscow, Politizdat Publ., 1977. 110 p. (Rus).

7. Available at: http://rvsn.ruzhany.info/raznoe/jangel2.html (accessed 24 June 2018). (Rus).

8. Strazheva I.V. Tiul'pany s kosmodroma [Tulips from a space center]. Moscow, Molodaia gvardiia Publ., 1978. 399 p. (Rus).
9. Available

at: https://www.yuzhnoye.com/company/history/rk r 12.html (accessed 14 June 2017). (Rus).

10. Available

at:

https://www.yuzhnoye.com/company/history/first-generationmilitary-rockets.html (accessed 04 February 2018). (Rus).

11. Baranov M.I. An anthology of the distinguished achievements in science and technique. Part 50: Rocket-space technology designer Wernher von Braun and his accomplishments in missile design. Electrical engineering \& electromechanics, 2019, no.4, pp. 3-11. doi: 10.20998/2074272X.2019.4.01.

12. Available at: https://gorod.dp.ua/tema/persons/?pageid=211 (accessed 11 March 2018). (Rus).

13. Available

at:

https://www.yuzhnoye.com/company/history/second-

generation-military-rockets.html (accessed 11 May 2017). (Rus).

14. Available at: http://oruzhie.info/raketi/405-r-36m (accessed 21 April 2018). (Rus).

15. Available at: https://www.yuzhnoye.com/company/history/ third-generation-military-rockets.html (accessed 16 May 2018). (Rus).

16. Andreev L.V., Konyukhov S.N. Yangel. Uroki i nasledie [Lessons and legacy]. Dnepropetrovsk, Art-Press Publ., 2001. 521 p. (Rus).

17. Available

at:

https://www.yuzhnoye.com/company/history/utkin.html

(accessed 26 July 2018). (Rus).

18. Available at: http://oruzhie.info/raketi/404-mr-ur-100 (accessed 06 December 2017). (Rus).

19. Available at:

https://www.yuzhnoye.com/company/history/konyuhov.html (accessed 15 January 2018). (Rus).

20. Available https://www.yuzhnoye.com/company/history/fourth-generationmilitary-rockets.html (accessed 05 September 2018). (Rus).

21. Available

http://www.warheroes.ru/hero/hero.asp?id=12779 (accessed 18 April 2018). (Rus).

22. Available

http://www.warheroes.ru/hero/hero.asp?id=12781 (accessed 30 May 2018). (Rus).

23. Platonov V.P. Iangel' sozdatel' oruzhiia vyzhivaniia [Yangel creator of weapon of survival]. Dnepropetrovsk, IMA-Press Publ., 2011. 528 p. (Rus).

24. Available

http://www.warheroes.ru/hero/hero.asp?Hero id=12072

(accessed 13 May 2018). (Rus).

Received 03.05.2019

M.I. Baranov, Doctor of Technical Science, Professor,

Scientific-\&-Research Planning-\&-Design Institute «Molniya», National Technical University «Kharkiv Polytechnic Institute», 47, Shevchenko Str., Kharkiv, 61013, Ukraine, phone +380577076841 ,

e-mail: baranovmi@kpi.kharkov.ua

\section{How to cite this article:}

Baranov M.I. An anthology of the distinguished achievements in science and technique. Part 52: Rocket-space technology designer Mikhail Yangel and his accomplishments in missile design. Electrical engineering \& electromechanics, 2019, no.6, pp. 3-11. doi: 10.20998/2074-272X.2019.6.01. 